\title{
Optic nerve sheath decompression for the treatment of visual failure in chronic raised intracranial pressure
}

\author{
J F Acheson, W T Green, M D Sanders
}

\begin{abstract}
The records of all patients undergoing optic nerve sheath decompression for visual failure in chronic raised intracranial pressure performed over a 15 year period have been reviewed. The aim was to study the visual outcome and relation to any shunting procedures. Fourteen patients (20 eyes) were identified in whom follow up information of at least one year was available. Eleven patients had benign intracranial hypertension (idiopathic intracranial hypertension) and three had dural venous sinus occlusive disease. Eight patients had unilateral surgery and six had bilateral surgery. Visual acuity and fields either improved or stabilised in 17 out of 20 eyes and three deteriorated. Of the eight patients undergoing unilateral surgery, the other eye remained stable in seven and deteriorated in one. Four patients required optic nerve sheath decompression despite previous shunting or subtemporal decompression. Five patients required shunts or subtemporal decompression after optic nerve sheath decompression because of persistent headache in three cases and for uncontrolled visual failure in two cases. No patients lost vision as a direct consequence of surgery. It is concluded that optic nerve sheath decompression is a safe and important therapeutic option in the management of chronic raised intracranial pressure complicated by visual loss. Vision can be saved after shunt failure, and in other cases may be maintained without the need for a shunt. Shunts may still be required, however, after optic nerve sheath decompression, especially for persistent headache.
\end{abstract}

(F Neurol Neurosurg Psychiatry 1994;57:1426-1429)

At least $50 \%$ of patients with benign intracranial hypertension (pseudotumour cerebri, idiopathic intracranial hypertension) develop visual loss over a period of time and up to $10 \%$ may have pronounced field and acuity deficits. ${ }^{1}$

It is now established that fashioning a window (fenestration) in the retrolaminar optic nerve sheath may relieve axoplasmic stasis and protect the optic nerve head from irreversible nerve fibre loss in chronic papilloedema. ${ }^{23}$ We report our results of optic nerve sheath decompression performed on a group of patients with chronic raised intracranial pressure and visual failure and the relation between optic nerve sheath decompression, visual outcome, and other CSF diversion procedures.

\section{Materials and methods}

Out of 23 identified cases on whom optic nerve sheath decompression had been performed, adequate follow up data of at least one year was available in 14 .

All patients were referred by physicians and ophthalmologists to the neuro-ophthalmology clinic at the National Hospital for Neurology and Neurosurgery. Each underwent detailed ophthalmic evaluation including refraction and best corrected Snellen acuity, quantitative kinetic perimetry (Goldmann fields using modified ArmalyDrance strategy for detection of disc related field loss), dilated fundoscopy, and fundus photography with fluorescein angiography. Space occupying lesions and hydrocephalus were excluded by CT (and by MRI in the most recent patients). All patients had at least two measurements of CSF opening pressure in excess of $25 \mathrm{~cm}$ water, normal CSF constituents, and angiography as appropriate. There were 11 cases of benign (idiopathic) intracranial hypertension, two cases of dural venous sinus thrombosis, and one of bilateral glomus jugulare tumour. Optic nerve sheath decompression was performed after demonstrating progressive peripheral, arcuate, or altitudinal field loss in addition to enlargement of the blind spot or uncontrollable visual obscurations in one or both eyes.

All cases had failed to respond adequately to maximal medical treatment and four had continued to have progressive visual failure after shunting or subtemporal decompression. Maximal medical treatment included supervised weight loss and carbonic anhydrase inhibitor (acetazolamide up to $1 \mathrm{~g}$ daily). Five patients were treated with loop diuretics (frusemide) and corticosteroids for short periods. Serial lumbar punctures were not used as a part of treatment.

The more severely affected eye was 
Left eye
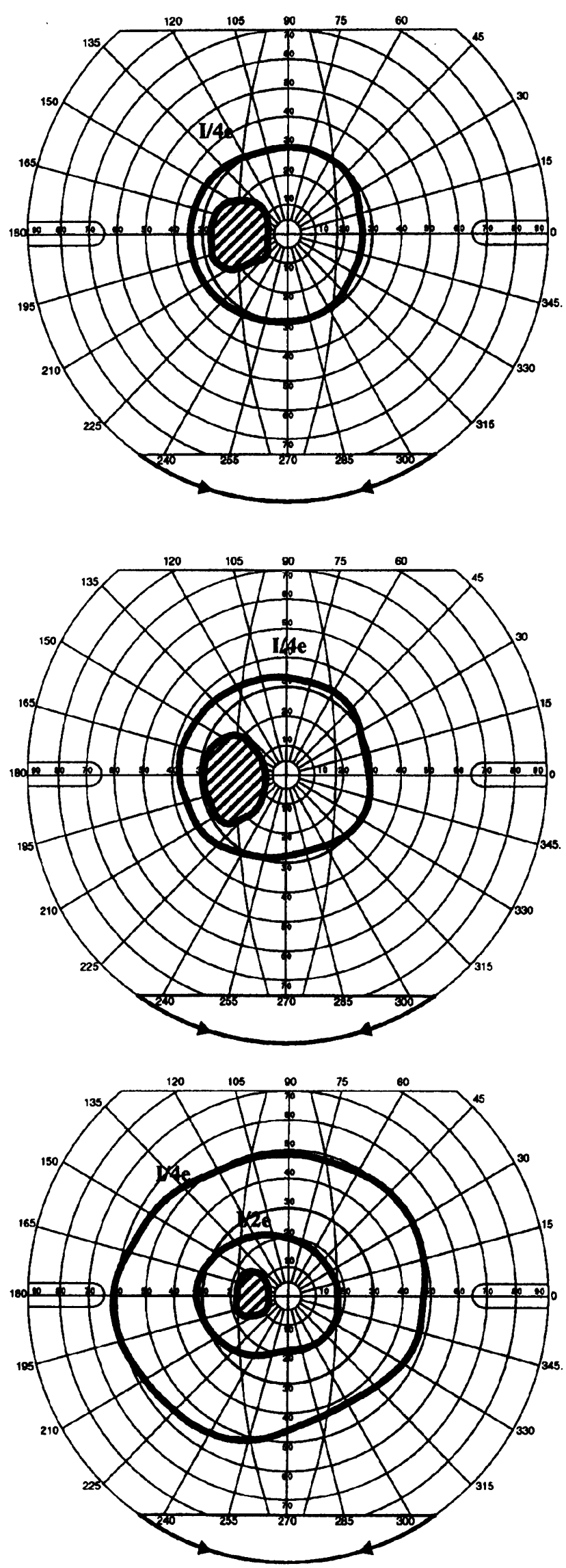

Right eye
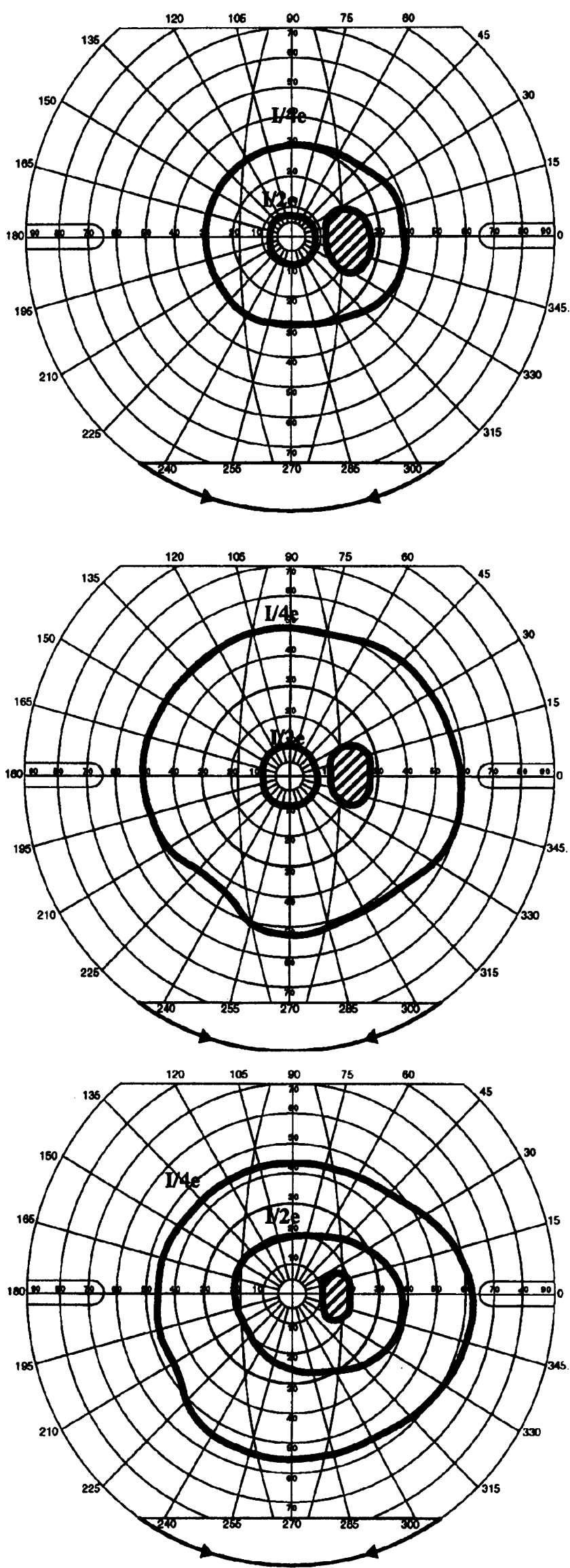

Summary of visual fields and acuities over follow up period in case 13. Top (March 1988, VAR 6/6, VAL 6/6); shortly before bilateral optic nerve sheath decompression showing pronounced constriction and blind spot enlargement in both eyes. Middle (fanuary 1989, VAR 6/6, VAL 6/6); eight months after right and one day before left optic nerve sheath decompression. Expansion in right field and no change in the left. Bottom (7anuary 1991 , VAR 6/6, $V A L$ 6/6); two years after second optic nerve sheath decompression. Expansion of left field and further improvement in I/2e isoptre on right. 
Clinical details of patients undergoing optic nerve sheath decompression (ONSD)

\begin{tabular}{|c|c|c|c|c|c|c|c|c|c|}
\hline Patient & $\begin{array}{l}\text { Age at } \\
\text { presentation }\end{array}$ & Diagnosis & Eye & $\begin{array}{l}\text { Preoperation } \\
\text { acuity }\end{array}$ & Preoperative field & Obscurations & $\begin{array}{l}\text { Postoperative } \\
\text { acuity } \\
\text { at } 6 \text { months }\end{array}$ & $\begin{array}{l}\text { Postoperative field } \\
\text { at } 6 \text { months }\end{array}$ & $\begin{array}{l}\text { Final } \\
\text { acuity }\end{array}$ \\
\hline \multirow[t]{2}{*}{$\stackrel{1}{\text { Male }}$} & \multirow[t]{2}{*}{41} & \multirow[t]{2}{*}{ BIH } & \multirow{2}{*}{$\begin{array}{l}\text { Left } \\
1984 \\
\text { Right } \\
1989\end{array}$} & $6 / 18$ & \multirow{2}{*}{$\begin{array}{l}\text { Large blind spot } \\
\text { Constriction } \\
\text { Large blind spot } \\
\text { Constriction }\end{array}$} & Yes & $6 / 6$ & $\begin{array}{l}\text { Blind spot normal } \\
\text { Expanded }\end{array}$ & $6 / 6$ \\
\hline & & & & $6 / 12$ & & Yes & $6 / 6$ & $\begin{array}{l}\text { Blind spot normal } \\
\text { Enlarged field }\end{array}$ & $6 / 6$ \\
\hline$\stackrel{2}{\text { Male }}$ & 50 & BIH & $\begin{array}{l}\text { Left } \\
1987\end{array}$ & $6 / 18$ & $\begin{array}{l}\text { Large blind spot } \\
\text { Constriction }\end{array}$ & Yes & $6 / 9$ & Normal & $6 / 9$ \\
\hline $\begin{array}{l}3 \\
\text { Male }\end{array}$ & 47 & BIH & $\begin{array}{l}\text { Right } \\
1985\end{array}$ & $6 / 5$ & Large blind spot & Yes & $6 / 5$ & Normal blind spot & $6 / 5$ \\
\hline \multirow[t]{2}{*}{$\begin{array}{l}4 \\
\text { Female }\end{array}$} & \multirow[t]{2}{*}{25} & \multirow[t]{2}{*}{ BIH } & \multirow{2}{*}{$\begin{array}{l}\text { Right } \\
1981 \\
\text { Left } \\
1981\end{array}$} & $6 / 6$ & Severe constriction & No & $6 / 5$ & Severe constriction & $6 / 5$ \\
\hline & & & & $6 / 18$ & Severe constriction & No & $6 / 5$ & Severe constriction & $6 / 5$ \\
\hline $\begin{array}{l}5 \\
\text { Female }\end{array}$ & 26 & BIH & $\begin{array}{l}\text { Right } \\
1983\end{array}$ & $6 / 6$ & $\begin{array}{l}\text { Large blind spot } \\
\text { Constriction }\end{array}$ & Yes & $6 / 6$ & $\begin{array}{l}\text { Large blind spot } \\
\text { Constriction }\end{array}$ & $6 / 9$ \\
\hline$\stackrel{6}{\text { Female }}$ & 53 & BIH & $\begin{array}{l}\text { Right } \\
1984\end{array}$ & $6 / 9$ & $\begin{array}{l}\text { Large blind spot } \\
\text { Constriction }\end{array}$ & Yes & $6 / 24$ & Further constriction & $6 / 60$ \\
\hline $\begin{array}{l}7 \\
\text { Female }\end{array}$ & 23 & BIH & $\begin{array}{l}\text { Left } \\
1989\end{array}$ & $6 / 9$ & $\begin{array}{l}\text { Large blind spot } \\
\text { Constriction }\end{array}$ & Yes & $6 / 6$ & $\begin{array}{l}\text { Normal blind spot } \\
\text { Less constricted }\end{array}$ & $6 / 6$ \\
\hline \multirow[t]{2}{*}{$\begin{array}{l}8 \\
\text { Female }\end{array}$} & \multirow[t]{2}{*}{32} & \multirow[t]{2}{*}{ BIH } & \multirow{2}{*}{$\begin{array}{l}\text { Right } \\
1978 \\
\text { Left } \\
1978\end{array}$} & & \multirow{2}{*}{$\begin{array}{l}\text { Large blind spot } \\
\text { Nasal constriction } \\
\text { Severe constriction }\end{array}$} & Yes & $6 / 9$ & Less constriction & $6 / 9$ \\
\hline & & & & HM & & Yes & $\mathrm{CF}$ & Less constriction & $\mathrm{CF}$ \\
\hline $\begin{array}{l}9 \\
\text { Male }\end{array}$ & 44 & BIH & $\begin{array}{l}\text { Left } \\
1990\end{array}$ & $6 / 9$ & Altitudinal defect & Yes & $6 / 5$ & Improved & $6 / 5$ \\
\hline $\begin{array}{l}10 \\
\text { Female }\end{array}$ & 24 & BIH & $\begin{array}{l}\text { Left } \\
1991\end{array}$ & $6 / 6$ & Large blind spot & Yes & $6 / 6$ & Normal blind spot & $6 / 6$ \\
\hline \multirow[t]{2}{*}{$\begin{array}{l}11 \\
\text { Female }\end{array}$} & \multirow[t]{2}{*}{43} & \multirow[t]{2}{*}{ BIH } & \multirow{2}{*}{$\begin{array}{l}\text { Right } \\
1992 \\
\text { Left } \\
1992\end{array}$} & $6 / 9$ & \multirow{2}{*}{$\begin{array}{l}\text { Large blind spot } \\
\text { Constriction } \\
\text { Large blind spot } \\
\text { Constriction }\end{array}$} & Yes & $6 / 12$ & Further constriction & $6 / 18$ \\
\hline & & & & $6 / 6$ & & Yes & $6 / 6$ & Less constriction & $6 / 6$ \\
\hline $\begin{array}{l}12 \\
\text { Male }\end{array}$ & 58 & $\begin{array}{l}\text { Sagittal } \\
\text { sinus } \\
\text { thrombosis }\end{array}$ & $\begin{array}{l}\text { Left } \\
1981\end{array}$ & $6 / 9$ & $\begin{array}{l}\text { Large blind spot } \\
\text { Constriction }\end{array}$ & No & $6 / 24$ & More constriction & NPL \\
\hline \multirow[t]{2}{*}{$\begin{array}{l}13 \\
\text { Male }\end{array}$} & \multirow[t]{2}{*}{34} & \multirow{2}{*}{$\begin{array}{l}\text { Lateral } \\
\text { sinus } \\
\text { thrombosis; } \\
\text { otitis } \\
\text { media }\end{array}$} & $\begin{array}{l}\text { Right } \\
1988\end{array}$ & $6 / 6$ & Constriction & Yes & $6 / 6$ & Less constriction & $6 / 6$ \\
\hline & & & $\begin{array}{l}\text { Left } \\
1989\end{array}$ & $6 / 6$ & Constriction & Yes & $6 / 6$ & Less constriction & $6 / 6$ \\
\hline \multirow[t]{2}{*}{$\begin{array}{l}14 \\
\text { Male }\end{array}$} & \multirow[t]{2}{*}{47} & \multirow[t]{2}{*}{$\begin{array}{l}\text { Bilateral } \\
\text { glomus } \\
\text { tumours }\end{array}$} & $\begin{array}{l}\text { Left } \\
1979\end{array}$ & $6 / 6$ & $\begin{array}{l}\text { Large blind spot } \\
\text { Constriction }\end{array}$ & Yes & $6 / 6$ & Expanded & $6 / 6$ \\
\hline & & & $\begin{array}{l}\text { Right } \\
1979\end{array}$ & $6 / 12$ & $\begin{array}{l}\text { Large blind spot } \\
\text { Constriction }\end{array}$ & Yes & $6 / 6$ & Expanded & $6 / 6$ \\
\hline
\end{tabular}

Data for patient 13 are illlustrated in the figure.

BIH = benign intracranial hypertension; ONSD = optic nerve sheath decompression

operated on initially, with second eye surgery only performed after the demonstration of further visual failure on that side after the first procedure. Follow up data were available for at least 12 months (mean two years) after optic nerve sheath decompression. Improved visual function was defined as improvement by at least two full lines of corrected Snellen chart acuity and in the Goldmann fields by an expansion of at least 15 degrees in two isoptres over two quadrants.

A medial transconjunctival approach was used under general anaesthetic. The medial rectus was disinserted and the globe fully abducted with the help of a traction suture attached to the disinserted muscle tendon. The medial intraconal orbital compartment was visualised directly under the operating microscope and the short posterior ciliary vessels reflected together with fascia bulbi and orbital fat using malleable retractors to expose the anterior optic nerve sheath. A window of nerve sheath of about $3 \times 4 \mathrm{~mm}$ was removed allowing free flow of CSF into the orbit. More recently we have created a larger $(4 \times 6 \mathrm{~mm})$ window in the dura but this was not done in the cases reported here. The medial rectus and conjunctiva were replaced using resorbable sutures.

\section{Results (table)}

A total of 20 eyes in 14 cases underwent optic nerve sheath decompression. In the 11 patients with a diagnosis of benign intracranial hypertension, eight were women and the mean age was 37 (range 24-50) years. The remaining three patients with other causes for pseudotumour cerebri were men with a mean age of 46 years.

Eleven eyes had reduced acuity before operation; of these five improved, three remained the same, and three deteriorated 


\begin{tabular}{|c|c|c|c|}
\hline $\begin{array}{l}\text { Final } \\
\text { field }\end{array}$ & $\begin{array}{l}\text { Final } \\
\text { obscurations }\end{array}$ & $\begin{array}{l}\text { Total } \\
\text { follow up }\end{array}$ & Comments \\
\hline Normal & Ceased & 7 years & $\begin{array}{l}\text { Lumbar-peritoneal shunt in } 1990 \text { for } \\
\text { uncontrolled headaches }\end{array}$ \\
\hline Normal & Ceased & 1 year & Preoperative gaze evoked amaurosis resolved \\
\hline Normal & Ceased & 1 year & No shunt \\
\hline Normal & Ceased & 1 year & No shunt \\
\hline No change & None & 3 years & Lumbar-peritoneal shunt in 1977 failed; \\
\hline No change & None & 3 years & $\begin{array}{l}\text { Subtemporal decompression } \\
\text { in } 1984 \text { for persistent headache }\end{array}$ \\
\hline Stable & Persisted & 7 years & $\begin{array}{l}\text { Disc swelling, obscurations and headache } \\
\text { persisted after ONSD Right disc and field } \\
\text { remained normal. Shunt in } 1984\end{array}$ \\
\hline Further loss & Persisted & 2 years & $\begin{array}{l}\text { Subtemporal decompression } 2 \text { months before } \\
\text { ONSD. } \\
\text { Lumbar-peritoneal shunt } 9 \text { months after ONSD } \\
\text { to relieve obscurations }\end{array}$ \\
\hline No change & Ceased & 1 year & $\begin{array}{l}\text { Lumbar-peritoneal shunt } 6 \text { months before } \\
\text { ONSD: failed }\end{array}$ \\
\hline Normal & Ceased & 4 years & No shunt \\
\hline Stable & Ceased & 4 years & No shunt \\
\hline Stable & Ceased & 18 months & No shunt \\
\hline Stable & Ceased & 2 years & $\begin{array}{l}\text { Other eye developed disc swelling and } \\
\text { obscurations after ONSD. Headaches } \\
\text { persisted; Lumbar-peritoneal shunt in } 1992\end{array}$ \\
\hline Further loss & Ceased & 1 year & No shunt \\
\hline \multirow[t]{2}{*}{ Improved } & Ceased & 1 year & \\
\hline & & 1 year & $\begin{array}{l}\text { Cortical venous infarction } 2 \text { weeks after ONSD. } \\
\text { No shunt }\end{array}$ \\
\hline Normal & Ceased & 7 years & $\begin{array}{l}5 \text { failed lumbar-peritoneal shunts before first } \\
\text { ONSD in } 1988\end{array}$ \\
\hline Normal & Ceased & 2 years & \\
\hline Stable & Ceased & 2 years & No shunt \\
\hline Stable & Ceased & 2 years & \\
\hline
\end{tabular}

after surgery. In nine eyes with normal preoperative visual acuity this remained stable after surgery. All 20 eyes had an abnormal visual field before surgery (blind spot enlargement and constriction); 12 of these improved, five remained unchanged, and three deteriorated. Obscurations were prominent in 12 patients and were relieved in 10 . In the eight patients undergoing unilateral surgery, the other eye had a normal field and acuity at the time of operation and seven remained stable. In case 10 the operated eye improved but the other eye went on to develop papilloedema and obscurations together with deteriorating headache and the patient required a lumbarperitoneal shunt.

Four patients came to optic nerve sheath decompression after other surgery for benign intracranial hypertension: three of these had had lumbar peritoneal shunts that had failed (one after four revisions) and the fourth had had a subtemporal decompression that had also failed.
Five patients required subsequent surgery. This was for persistent headache (cases 1 and 4), unrelieved visual failure (cases 5 and 6), or both (case 10). One had a subtemporal decompression and the others were given shunts.

\section{Discussion}

Medical measures to control headache and visual symptoms in chronic raised intracranial pressure may be both ineffective and poorly tolerated. These measures include weight loss, carbonic anhydrase inhibitors, corticosteroids, and serial lumbar punctures. Surgical CSF diversion procedures designed to reduce intracranial pressure are more effective but there is a significant long term failure rate. ${ }^{4}$ Furthermore, progressive visual failure in the presence of a functioning shunt may occur. For these reasons, relief of CSF pressure on the distal optic nerve by the direct approach of optic nerve sheath decompression is an attractive option in cases in which visual loss is prominent.

Evidence for the efficacy of optic nerve sheath decompression continues to accumulate. In the series of Corbett et $a l^{2}$ of 28 patients and 40 eyes, there was improved or stabilised acuity in 33 eyes. In the series by Sergott et $a l^{5} 21$ eyes improved out of 29 operated on in 21 patients, and similar results have been reported by others. The procedure is not without risk, and permanent visual loss as a result of intraoperative axonal or vascular damage has been described. ${ }^{6}$

A medial transconjunctival approach is usually preferred to the alternative operation by lateral orbitotomy. This is because the surgical approach to the optic nerve sheath from the lateral side is technically more complex. There are greater risks of damage to the ciliary ganglion resulting in a dilated pupil and accommodation paresis, and to nerve fibres serving central vision, which lie on the lateral side of the retrolaminar optic nerve. In our series there were no instances of optic nerve damage directly attributable to the operation.

In conclusion, we believe that optic nerve sheath decompression can play an important part in the management of patients with visual failure in pseudotumour cerebri. Vision can be restored in patients for whom shunts have been unsuccessful, and other patients may maintain vision with optic nerve sheath decompression without requiring a shunt. Shunts may still be required after optic nerve sheath decompression, however, especially to control headaches.

1 Orcutt JC, Page NGR, Sanders MD. Factors affecting visual loss in benign intracranial hypertension visual loss in benign intra
Ophthalmology 1984;91:1303-12.

2 Corbett JJ, Nerad JA, Tse DT, Anderson RL. Results of optic nerve sheath fenestration for pseudotumour cerebri. Arch Opthalmol 1988;106:1391-7.

3 Brourman ND, Spoor TC, Ramocki JM. Optic nerve sheath decompression for pseudotumour cerebri. Arch Ophthalmol 1988;106:1378-83.

4 Rosenberg ML, Corbett JJ, Smith C, et al. CSF diversion procedures in pseudotumour cerebri. Neurology 1993; 43:1071-2.

5 Sergott RC, Savino PJ, Bosley JM. Modified optic nerve sheath decompression provides long-term visual improvement for pseudotumour cerebri. Arch Opthalmol 1988;106:1384-90.

6 Plotnik JL, Kosmorsky GS. Operative complications of optic nerve sheath decompression. Ophthalmology 1993;100:683-90. 